WATER-RESOURCES INVESTIGÁTIONS OF THE

U.S. GEOLOGICAL SURVEY IN NEW MEXICO--

FISCAL YEAR 1980

Compiled by Robert R. White

U.S. GEOLOGICAL SURVEY

Open-File Report $82-267$

Albuquerque, New Mexico

February 1982 
UNITED STATES DEPARTMENT OF THE INTERIOR

James G. Watt, Secretary

GEOLOGICAL SURVEY

Dallas L. Peck, Director

For additional information write to:

District Chief U.S. Geologica1 Survey, WRD Western Bank Building, Rm 720 505 Marquette NW, Albuquerque, New Mexico 87102
For sale by:

National Technical Information Center U.S. Department of Commerce 528 Port Royal Road Springfield, VA 22151 


\section{PREFACE}

This is the third in a series of annual reports in which the program of the New Mexico District, U.S. Geological Survey Water Resources Division, is summarized. This report may be of use to cooperating agencies and to the users of water data in that is summarizes and gives the status of the basic data-collection program and all current studies of the Water Resources Division in New Mexico. The program of the New Mexico District is, for the most part, accomplished through cooperative programs with other Federal and non-Federal agencies. 
Surface-water data $\ldots \ldots \ldots \ldots \ldots \ldots \ldots \ldots \ldots \ldots \ldots \ldots \ldots \ldots \ldots$. 7

Ground-water data .............................. 9

Chemical and biological water-quality data $\ldots \ldots \ldots \ldots \ldots \ldots \ldots . \ldots 11$

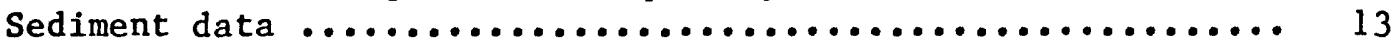

Interpretive hydrologic investigations $\ldots \ldots \ldots \ldots \ldots \ldots \ldots \ldots \ldots \ldots . \ldots$

Hydrologic investigations of the Acoma Pueblo, New Mexico ... 15

Urban flood-hydrology of Albuquerque area, New Mexico ...... 15

Investigation and analysis of floods for small drainage

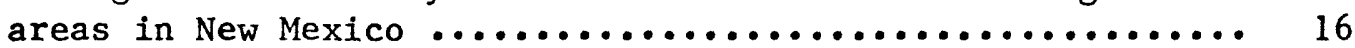

High Plains regional aquifer system analysis (New Mexico) ... 16

Hydrologic investigations of the Laguna Pueblo, New Mexico .. 17

Digital model study of the Mimbres Basin, New Mexico ........ 17

Miscellaneous activities under the State Engineer program ... 18

New Mexico District data bank ........................ 18

Water use - New Mexico ............................... 19

Quality-of-water monitoring in Chaco River Basin in northwestern New Mexico's energy development area ........ 20

Hydrologic surveillance of coal-lease areas in northwestern New Mexico .................................... 21

Water-resources monitoring of coal development in the

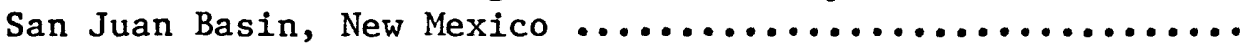

Effects of energy-resources development on the hydrogeologic environment of northwestern New Mexico .................

Precipitation-runoff modeling of watershed systems in

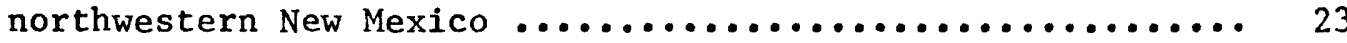

Miscellaneous reach studies, Pecos River ................ 23

Duties for the Rio Grande Compact Commission .............. 24

A quantitative analysis of the ground-water system in the Roswell basin, Chaves and Eddy Counties, New Mexico ....... Ground-water resources of the San Agustin Plains and adjacent areas, Catron and Socorro Counties, New Mexico ...........

Water resources of Santa Fe County, New Mexico ............. 
Projects in Progress in Fiscal Year 1980 - Continued:

Interpretive hydrologic investigations - Continued:

Southwest alluvial basin (east), reglonal aquifer systems

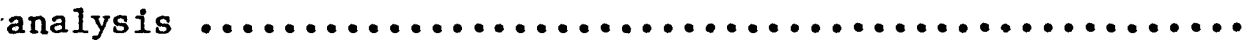

Reconnaissance of water resources available to urban areas,

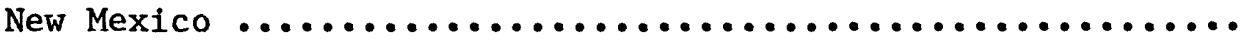

Continuing reconnaissance and evaluation of water resources on the White Sands Missile Range ....................

Hydrologic investigations related to a radioactive-waste repository in salt, southeastern New Mexico ............ 28

Water resources of the Zuni Reservation ................ 28

Ground-water resources of central and western Valencia, County, New Mexico ............................... 29

Dig1tal-model study of the Roswell basin, New Mexico ....... 29

Model of the Ogallala aquifer system, Lea County, New Mexico ................................... 30

Exploration of techniques for separation and quantification of Individual coal-mine effects from cumulative effect data

Publications of the U.S. Geological Survey and reference sources on the hydrology and geology of New Mexico ........................

Published reports of the New Mexico District, 1980 ................

\section{ILLUSTRATIONS}

Figure 1. Map showing location of offices of the New Mexico District and areas of responsibility

2. Map of New Mexico showing location of surface-water gaging

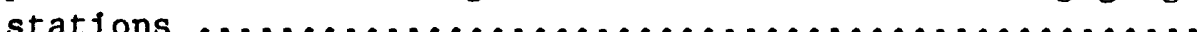

3. Map showing areas with many ground-water observation wells in New Mexico ................................

4. Map of New Mexico showing location of water-quality gaging stations

5. Map showing location of interpretive hydrologic investigations 


\title{
WATER-RESOURCES INVESTIGATIONS OF THE U.S - GEOLOGICAL SURVEY \\ IN NEW MEXICO, FISCAL YEAR 1980
}

By Robert R. White

\begin{abstract}
The Water Resources Division of the U.S. Geological Survey investigates the occurrence, quantity, quality, distribution, and movement of the Nation's surface and underground waters, and coordinates the Federal water-data acquisition activities.

During fiscal year 1980, the New Mexico District had 28 active projects, released 24 reports, and answered hundreds of requests of water-related information.
\end{abstract}

\section{INTRODUCTION}

The U.S. Geological Survey, through its Water Resources Division, investigates the occurrence, quantity, quality, distribution, and movement of the surface and underground waters that comprise the Nation's water resources, and coordinates the Federal water-data acquisition activities.

The mission of the Division is accomplished through programs supported by the U.S. Geological Survey independent of or in cooperation with other Federal and non-Federal agencies. These programs involve:

1. Collecting, on a systematic basis, data needed for the continuing determination and evaluation of the quantity, quality, and use of the Nation's water resources.

2. Conducting analytical and interpretive water-resource appraisals describing the occurrence, availability, and the physical, chemical, and biological characteristics of surface and ground water. 
3. Conducting basic problem-oriented research in hydrology to improve the scientific basis for investigations and measurement techniques, and to predict quantitatively the response of hydrologic systems to stress.

4. Disseminating the water data and the results of these investigations and research through reports, maps, computerized information services, and other forms of public releases.

5. Coordinating the activities of Federal agencies in the acquisition of water data for streams, lakes, reservoirs, estuaries, and ground waters.

6. Providing scientific and technical assistance in hydrologic fields to other Federal, State, and local agencies, to licensees of the Federal Power Commission, and to international agencies on behalf of the Department of State.

The New Mexico District of the U.S. Geological Survey, Water Resources Division, along with other Federal and State agencies, shares in the responsibility for the appraisal of the quantity, quality, and distribution of surface- and ground-water resources of the State of New Mexico.

This report contains information concerning the U.S. Geological Survey's water-resources investigations and surveillance programs in New Mexico. The District office is located in Albuquerque with subdistrict offices and field headquarters located throughout the State (fig. 1). Requests for information should be addressed as follows:

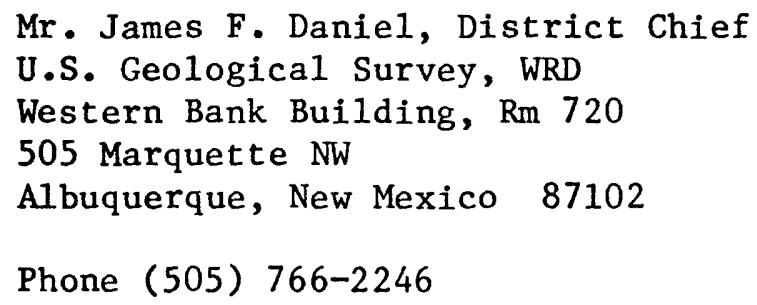

Current District programs include the following water-information areas:

1. Chemical quality of surface water in New Mexico

2. Chemical quality of ground water in New Mexico

3. Sediment transport in New Mexico streams

4. Surface-water supply

5. Surface-water diversions for irrigation 


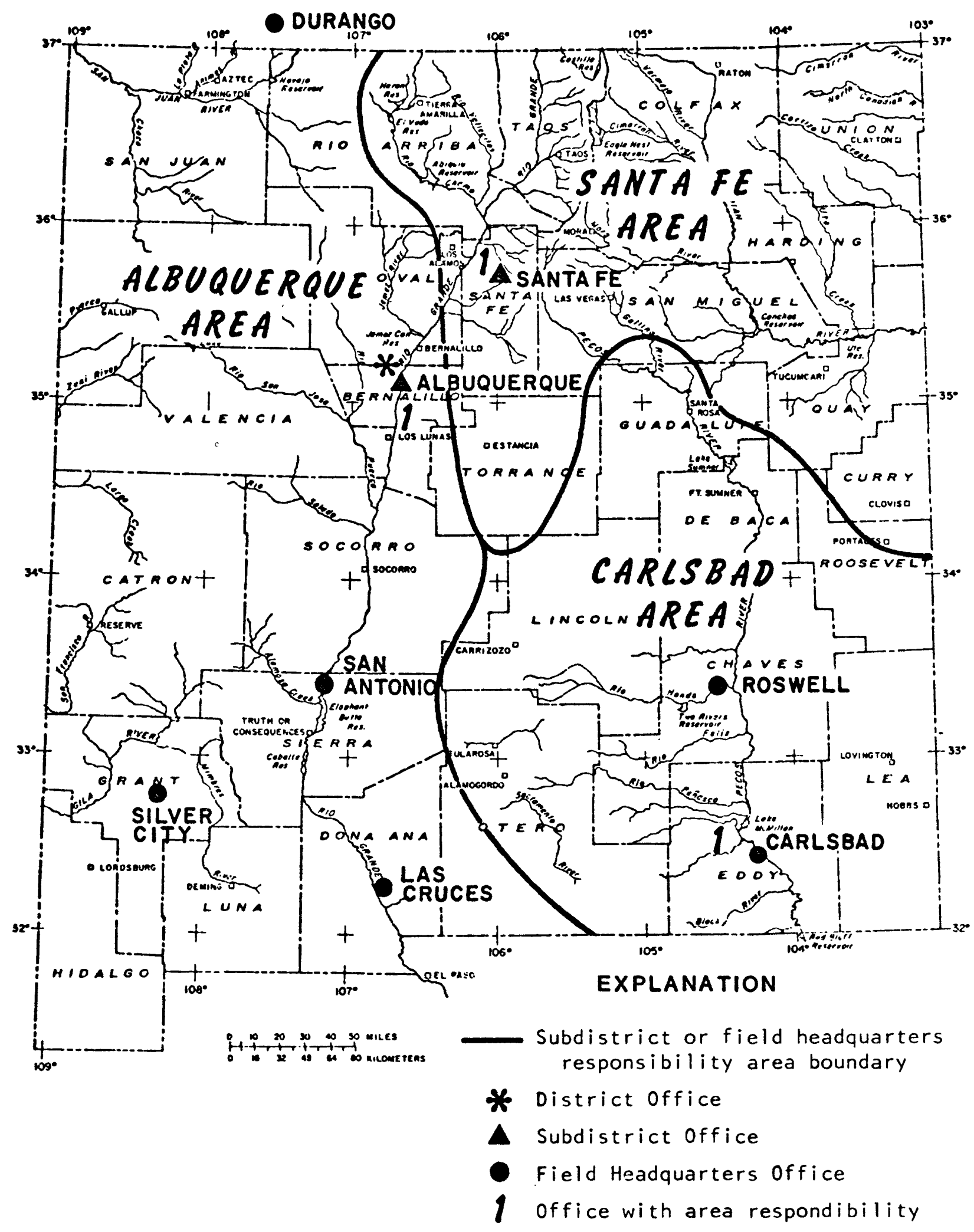

Figure 1.--Location of offices of the New Mexico District and areas of responsibility 
6. Streamflow characteristics

High flow

Low flow

Flood frequency

7. Effect of urban development on storm runoff

8. Inundation from floods

9. Effects of ground-water pumping

10. Long-term monitoring of ground-water levels

11. Ground-water and surface-water relationships

12. Consumptive use of phreatophytes

13. Hydrologic impacts of energy development

14. Ground-water supplies

15. Hydrologic impacts of ground-water development

During fiscal year 1980, the District had 28 active projects, released 24 reports and answered hundreds of requests for water-related information.

The programs of the District are supported by Federal funding to the Geological Survey and in cooperation with other Federal, State, and local agencies. Agencies that cooperated with the U.S. Geological Survey during fiscal year 1980 were:

$\underline{\text { State and Local }}$

Albuquerque Metropolitan Arroyo

Flood Control Authority

City of Albuquerque

Costilla Creek Compact Commission

New Mexico Bureau of Mines and

Mineral Resources

New Mexico Environmental

Improvement Division

New Mexico Interstate Stream

Commission

New Mexico State Engineer office

New Mexico State Highway

Department

Pecos River Commission

Pueblo of Acoma

Pueblo of Laguna

Pueblo of Zuni

Rio Grande Compact Commission

\section{Federal}

U.S. Department of Agriculture Forest Service Soil Conservation Service

U.S. Department of the Army Corps of Engineers White Sands Missile Range

U.S. Department of Energy

U.S. Department of Housing and Urban Development

U.S. Environmental Protection Agency

U.S. Department of the Interior Bureau of Indian Affairs Bureau of Reclamation National Park Service Bureau of Land Management 


\section{PROJECTS IN PROGRESS IN FISCAL YEAR 1980}

\section{Hydrologic-Data Program}

Hydrologic-data stations are maintained by the Geological Survey at locations in New Mexico. They constitute a network for obtaining records of stream stage and discharge, reservoir and lake elevation and storage, ground-water levels, well and spring discharge, and the quality of surface and ground water (figs. 2, 3, and 4). The Water Resources Division has both a current and a historical file of hydrologic data. Data collected are stored in the Geological Survey's National Water Data Storage and Retrieval System (WATSTORE) and are available on request. These data can be retrieved in machine-readable form as computer-printed tables or graphs, or digital plots. Computer programs are available for statistical analysis of the data, and the results of these analyses are available. Local assistance in acquisition of services or products from WATSTORE can be obtained from the District Chief, Water Resources Division, in Albuquerque.

A summary of each data collection program follows. The summary consists of a map showing the location of the hydrologic-data stations, a list of cooperating agencies, a brief description of the program's purpose and scope, and project reports released during the fiscal year. 


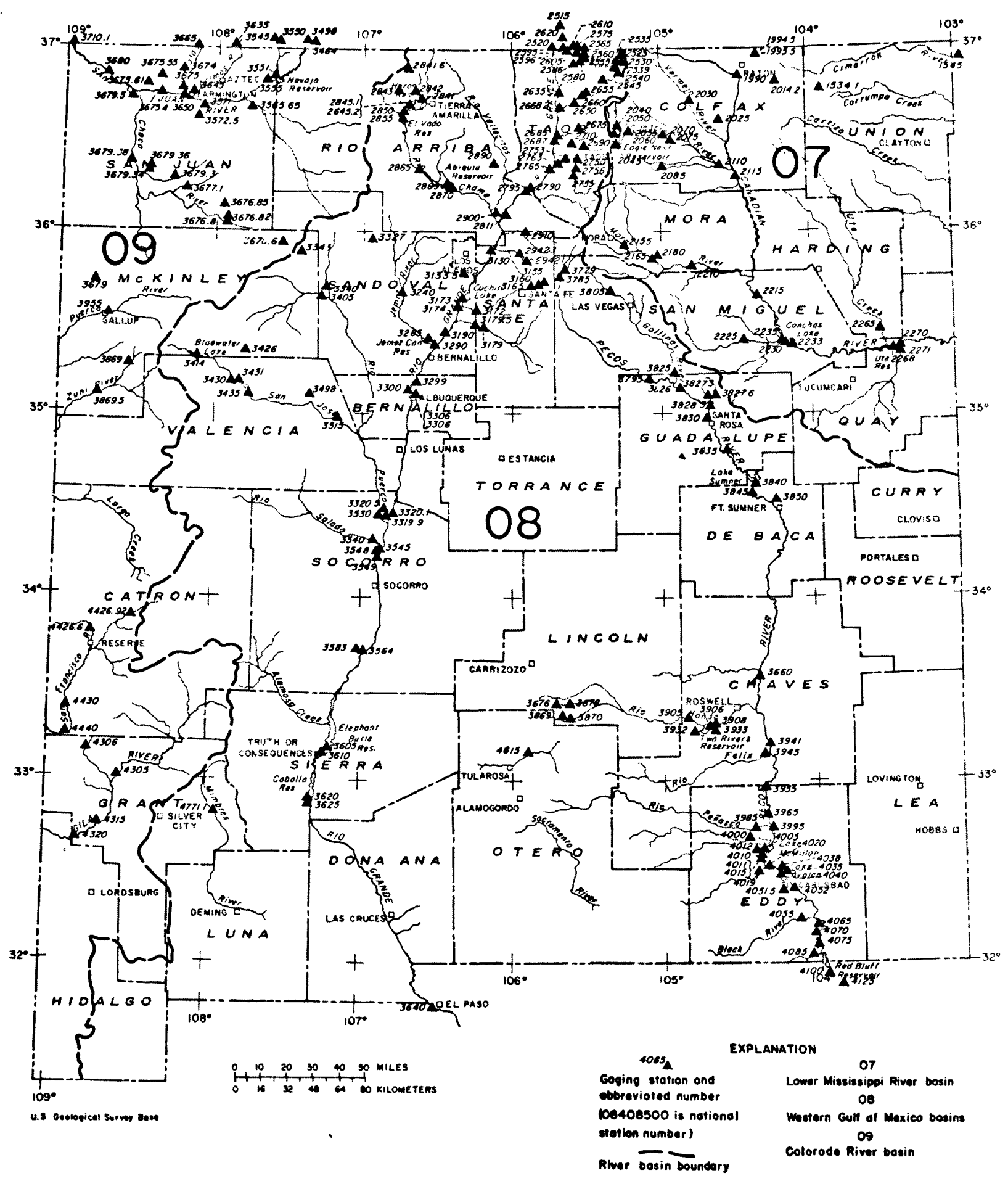

Figure 2. Mop of New Mexico showing location of surface-water gaging stations 
PROJECT TITLE: Surface-water data

LOCATION: Statewide

COOPERATING AGENCIES: New Mexico State Engineer office,

New Mexico Interstate Stream Commission,

Costilla Creek Compact Commission, Pecos River

Commission, Albuquerque Metropolitan Arroyo

Flood Control Authority, New Mexico

Environmental Improvement Division, Sol1

Conservation Service, Bureau of Reclamation,

National Park Service, Bureau of Indian

Affairs, Corps of Engineers, Forest Service, and Bureau of Land Management.

PROJECT CHIEF: Louis P. Denis (505-766-2011)

PERIOD OF PROJECT: Continuous since 1930

Purpose and scope: Surface-water discharge (streamflow) and stage (water level) are collected for general hydrologic purposes such as assessment of water resources, areal analysis, determination of long-term trends, research and special studies, or for management and operational purposes. In New Mexico, discharge and stage data currently are being obtained at the number of stations given below.

\section{Station classification}

Stream stations $\ldots \ldots \ldots \ldots \ldots \ldots \ldots \ldots \ldots \ldots \ldots$

Continuous stage and discharge record:

Water year.$\ldots \ldots \ldots \ldots \ldots \ldots \ldots \ldots \ldots \ldots \ldots \ldots$

Irrigation season only $\ldots \ldots \ldots \ldots \ldots \ldots \ldots \ldots$

Cumulative discharge record:

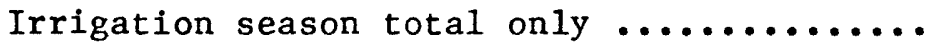

Partial stage and discharge record ..........

Lake and reservoir stations ................

Continuous stage and contents $\ldots \ldots \ldots \ldots \ldots \ldots$

Intermittent stage and contents ..........

Total
Number of

stations

399

169

38

39

153

24

18

6 
Al1 stations including those operated in support of other projects are shown on the map (fig. 2) except partial-record stations that record peak flow only (136), low flow (6), and selected stations operated only during irrigation season (126).

Note: In association with project work, there are 138 partial-record stations that record peak flow only, an additional 20 sites measured regularly, and 34 measured on an occasional basis.

Reports published or released during fiscal year 1980:

U.S. Geological Survey, 1980, Water Resources Data for New Mexico, Water Year 1979: U.S. Geological Survey Water-Data Report NM-79-1, 747 p. 
PROJECT TITLE: Ground-water data

LOCATION: Statewide

COOPERATING AGENCIES: New Mexico State Engineer office and Corps of Engineers

PROJECT CHIEF: Jim D. Hudson (505-766-2011)

PERIOD OF PROJECT: Continuous since 1925

Purpose and scope: Ground-water data are collected to determine short-range changes and long-range trends in ground-water levels, to relate these data to changes in ground-water storage, and to provide the data base necessary for management of the resource. Water levels in wells, discharge of springs and wells, and water-quality data are key parameters for monitoring ground-water trends; however, they must be integrated with other observations and studies of ground-water systems in order to have the fullest meaning and usefulness. A basic network of observation wells is maintained in New Mexico for monitoring fluctuations of water levels. Other wells known as "project we1ls" are used for specific (generally short-term) studies and, although they are not part of the basic observation-we11 network, data obtained from them also are available. Beginning in 1980, most wells are to be measured every five years on a rotating basis, and only selected areas will be published. Approximately 1,700 wells are currently being measured (project wells are not included).

Locations of individual observation wells are not shown; however, areas of many observation wells are shown in figure 3 .

Reports published or released during fiscal year 1980:

Hudson, J. D., 1980, Ground-water depletion, in feet, allowed in a part of Curry County, New Mexico, by U.S. Internal Revenue Service for calendar year 1979: New Mexico State Engineer Map CU-20, 1 sheet.

1980, Ground-water depletion, in feet, allowed in the central part of Lea County, New Mexico, by U.S. Internal Revenue Service for calendar year 1979: New Mexico State Engineer Map LC-22, 1 sheet.

1980, Ground-water depletion, in feet, allowed in the northern part of Lea County, New Mexico, by U.S. Internal Revenue Service for calendar year 1979: New Mexico State Engineer Map LN-22, 1 sheet.

1980, Ground-water depletion, in feet, allowed in Portales Valley, Roosevelt County, New Mexico, by U.S. Internal Revenue Service for calendar year 1979: New Mexico State Engineer Map R0-23, 1 sheet.

U.S. Geological Survey, 1980, Water Resources Data for New Mexico, Water Year 1979: U.S. Geological Survey Water-Data Report NM-79-1, p. 681-742. 


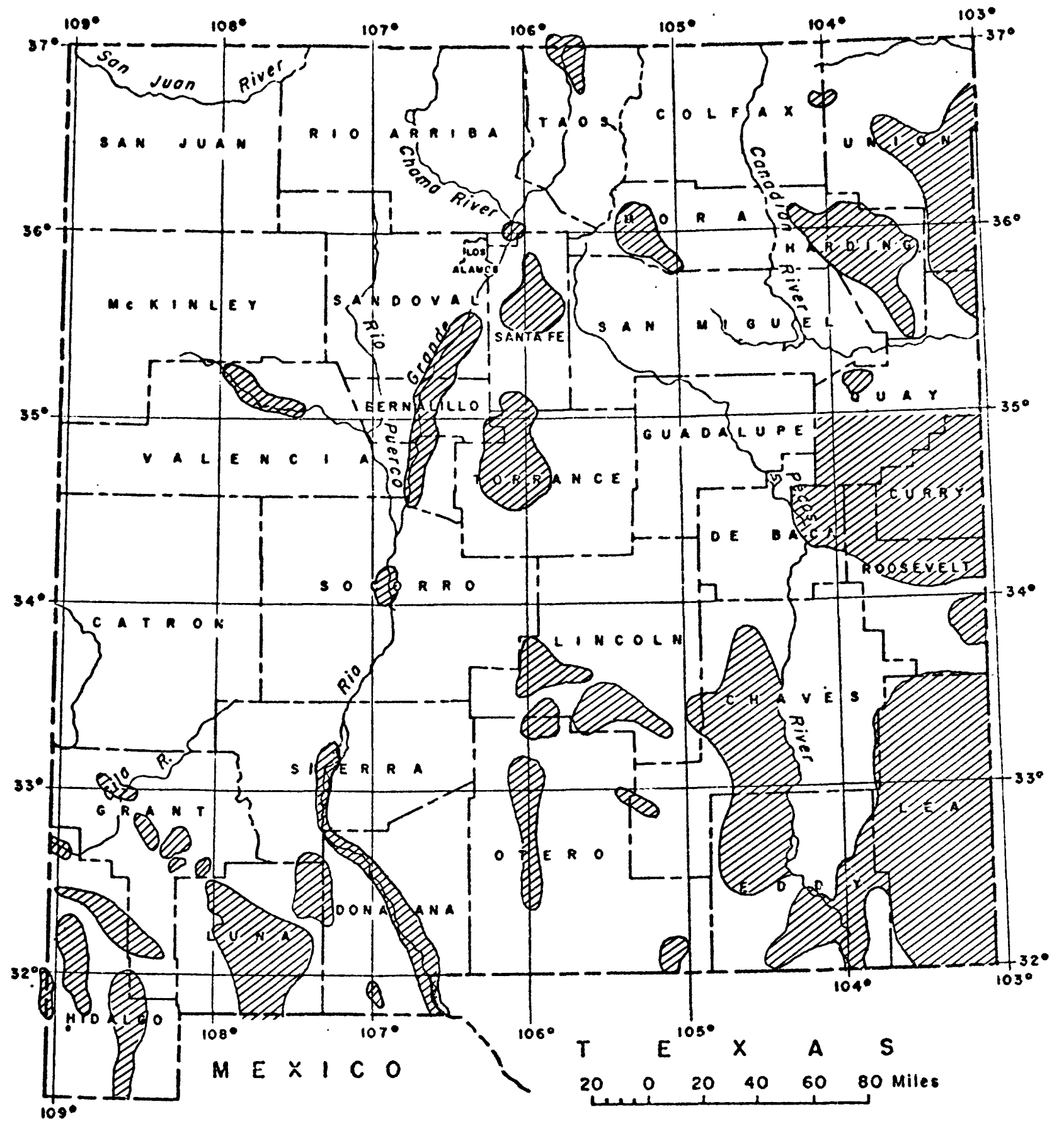

Figure 3.--Areas with many ground-water observation wells in New Mexico. 
PROJECT TITLE: Chemical and biological water-quality data

LOCATION: Statewide

COOPERATING AGENCIES: New Mexico State Engineer office, New Mexico Interstate Stream Commission, Pecos River Commission, City of Albuquerque, National Park Service, Bureau of Reclamation, and Bureau of Land Management

PROJECT CHIEF: Richard L. Lepp (505-766-2011)

PERIOD OF PROJECT: Continuous since 1937

Purpose and scope: The chemical and biological water-quality program provides for the collection, analysis, storage, and publication of data from a network of surface- and ground-water sites in New Mexico.

Chemical and biological water-quality data are obtained at 77 continuingrecord stations for surface water. Data is also collected at numerous partial-record stations and miscellaneous sites. These stations are used to monitor the quality of surface water in New Mexico. Some of these stations also are part of the Geological Survey nationwide network known as the National Stream Quality Accounting Network (NASQAN), which is used to detect nationwide trends in water quality. The types of data determined at the continuing-record stations are given in the following table:

$$
\text { Data classification } \quad \text { sites }
$$

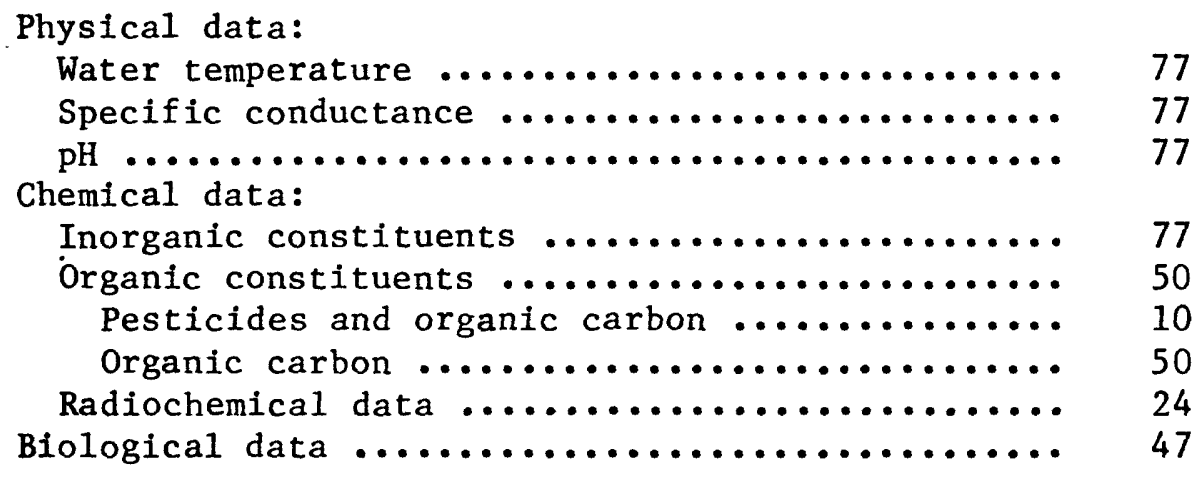

Miscellaneous water-temperature data, recorded at the time streamflow measurements are made, are avallable from the subdistrict offices.

Chemical water-quality data for ground water was also obtained in conjunction with project activities. (In 1980, approximately 330 sites were sampled).

Reports published or released during fiscal year 1980:

U.S. Geological Survey, 1980, Water Resources Data for New Mexico, Water Year 1979: U.S. Geologica1 Survey Water-Data Report NM-79-1, 747 p. 


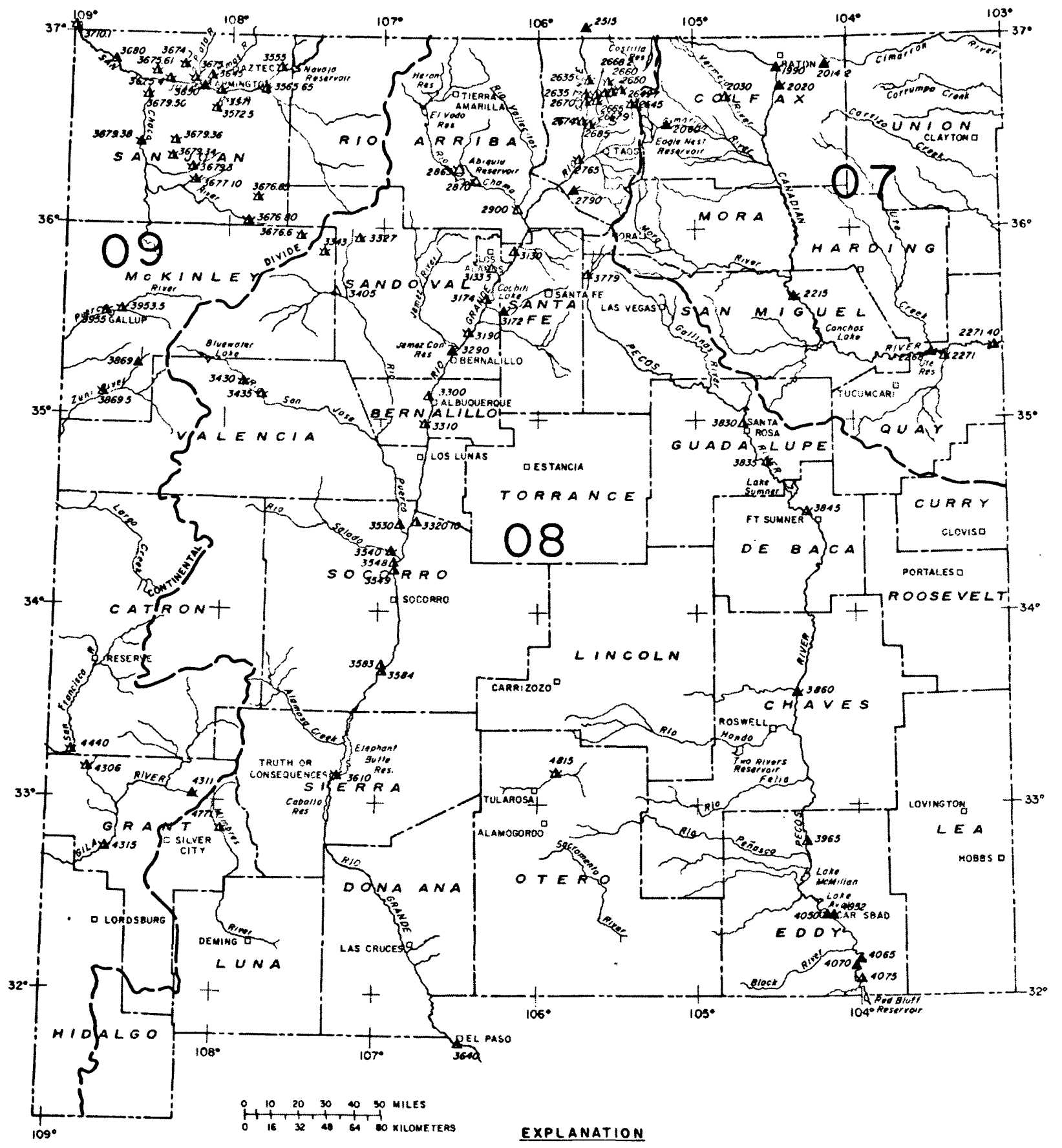

U.s Oentogicel Survey beso

STATION AND SAMPLING FREQUENCY

Chemical quality: $\triangle$ daily $\triangle$ other than doily

Suspended sediment: $\Delta$ doily $\Delta$ other then doily

Chemical quolity ond

Suspended sediment: 4 both doily both other than dolly

A daily chemicol doily suspended quality ond sediment and other than doily doily suspended chemicol quality endiment
BASIN AND STATION NUMBER Rlver bosin boundory: ح

Lower Mississippi River bosin number: 07

Western Gulf of Maxico bosin number: 08

Colorodo River bosin number: 09 $4^{227100}$

Number by symbol is obbreviated

station number. Complate stotion

number of example is:

$$
\text { 우 } 227140
$$

Figure 4. Map of New Mexico showing locotion of water-quality goging stotions. 
PROJECT TITLE: Sediment data

LOCATION: Statewide

COOPERATING AGENCIES: New Mexico State Engineer Office, New Mexico

Interstate Stream Commission, National Park

Service, Corps of Engineers, Bureau of Land

Management, and Bureau of Reclamation

PROJECT CHIEF: David E. Funderburg (505-766-2011)

PERIOD OF PROJECT: Continuous since 1937

Purpose and scope: The purpose of this project is to determine the load, size, and nature of sediment carried in New Mexico streams. Data is collected to provide information for the evaluation of sources and sinks of sediment, effects of changing land use, effects of water management on channel stability, and regional base-line conditions.

Sediment data is collected at 85 sites in New Mexico. At 15 of these sites a continuous record of sediment load is computed from samples collected by local observers and (or) automatic samplers that collect at least a daily sample. Samples are collected more frequently during high-water runoff periods. The remaining sites are sampled intermittently and during peak runoff periods.

Reports published or released during fiscal year 1980:

U.S. Geological Survey, Water Resources Data for New Mexico, Water Year 1979: U.S. Geological Survey Water-Data Report NM-79-1, 747 p. 


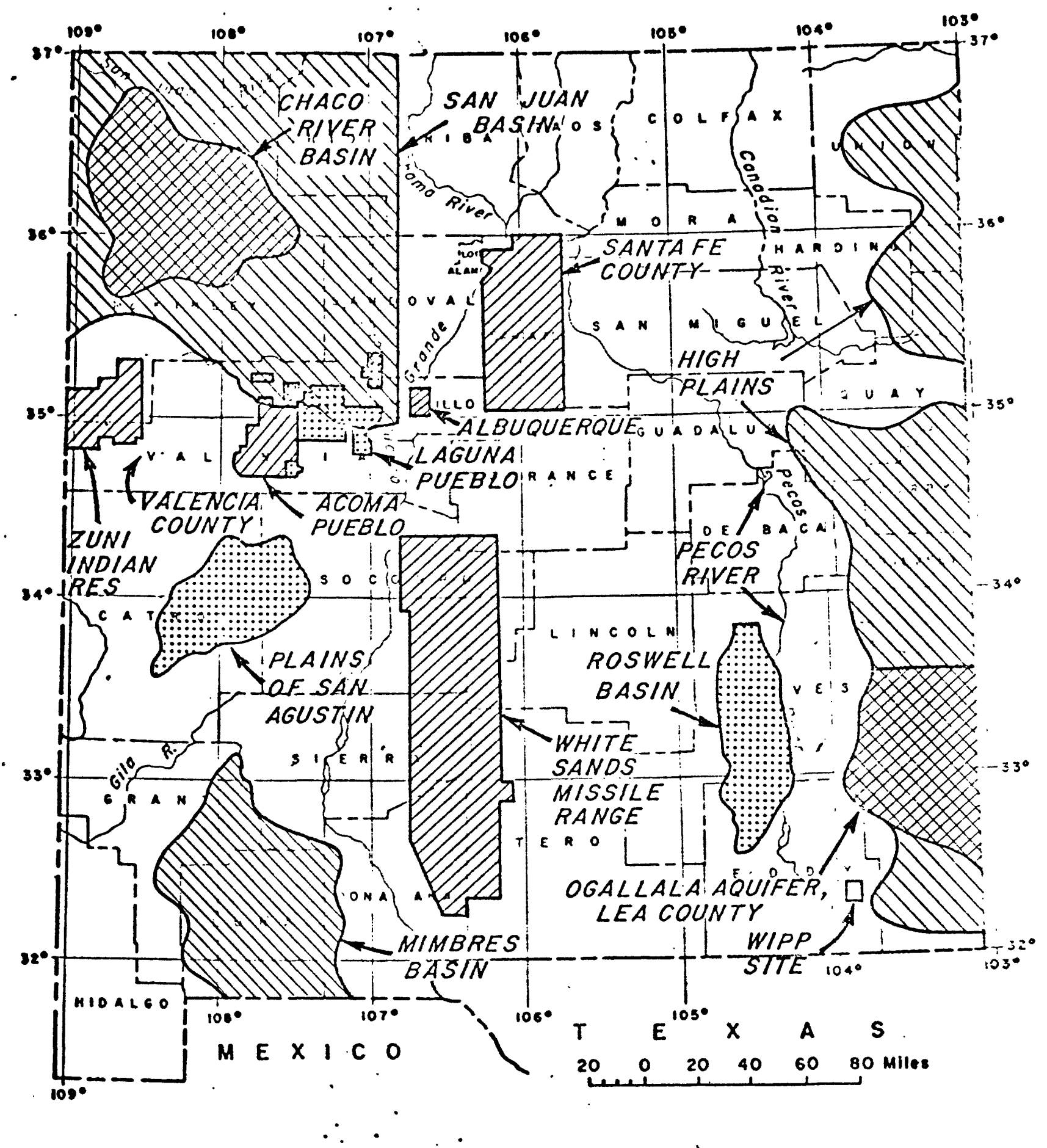

Figure 5. Location of interpretive hydrologic investigations. 


\section{Interpretive Hydrologic Investigations}

Hydrologic investigations include areal resource appraisals, data collection other than part of the hydrologic-data program, and research activities. A summary of each of the investigations follows and consists of a brief statement of the problem, objectives, and reports released during the fiscal year. The location of these studies is shown in figure 5.

PROJECT TITLE:

Hydrologic investigations of the Acoma Pueblo, New Mexico

COOPERATING AGENCY: Bureau of Indian Affairs

PROJECT CHIEF: Dennis W. Risser

PERIOD OF PROJECT: October 1977 to September 1980

Problem: Acoma Pueblo needs additional supplies of good-quality water for irrigation and public supply.

Objectives: Determine the quantity and quality of water available and the possible effects of present and future water-resources development on the hydrologic system.

PROJECT TITLE: Urban flood-hydrology of Albuquerque area, New Mexico

COOPERATING AGENCIES: Albuquerque Metropolitan Arroyo Flood Control Authority and City of Albuquerque

PROJECT CHIEF: John P. Borland

PERIOD OF PROJECT: Continuous since February 1976

Problem: The City of Albuquerque and the Albuquerque Metropolitan Arroyo Flood Control Authority require reliable flood-frequency data for the design of urban drainage structures and the regulation of urban development. Present methodology uses unverified empirical relations and data from other urban areas. There is little data presently available regarding the chemical quality of storm runoff in the Albuquerque area. 
Objectives: Define runoff characteristics from urban basins in the Albuquerque area and relate the characteristics to measurable basin and climatic varlables. Investigate the applicability of empirical relations developed for other urban areas to the Albuquerque area, specifically, relations used to compute time and peak coefficients used in the Colorado urban hydrograph procedure. Develop relations between magnitude of flood discharges and measurable basin and climatic variables for watersheds in the Albuquerque area and provide estimates of chemfcal quality of runoff.

PROJECT TITLE:

Investigation and analysis of floods for small

drainage areas in New Mexico

COOPERATING AGENCY: New Mexico State Highway Department

PROJECT CHIEF: Richard P. Thomas

PERIOD OF PROJECT: August 1966 to June 1980

Problem: The State Highway Department needs data on the frequency and magnitude of floods to better design highway drainage structures.

Objectives: Collect and analyze hydrologic data which can be used in the design of highway drainage structures. Relate the magnitude and frequency of floods to basin or channel geometry characteristics. One hundred and thirtyeight (138) gages are operated for peak flow only (crest-stage gages) under this project.

PROJECT TITLE: High Plains regional aquifer

system analysis (New Mexico)

PROJECT CHIEF: $\quad$ D. L. Hart, Jr.

PERIOD OF PROJECT: October 1977 to September 1982

Problem: The Ogallala aquifer underlies about 150,000 square miles of land in eight Western States. This study is part of a regional evaluation of the Ogallala aquifer. The aquifer underlies about 11,000 square miles of land in New Mexico and has experienced severe water-level declines due to pumpage for irrigation and municipal use.

Objectives: Determine the quantity and quality of the water resource and the operation of the system by collecting and analyzing data about hydrologic properties, recharge, quantity of pumpage, and distribution of pumpage. Provide the hydrologic evaluation needed to predict the response of the ogallala aquifer to future pumpage. 
PROJECT TITLE: Hydrologic investigations of the Laguna Pueblo, New Mexico

COOPERATING AGENCY: Bureau of Indian Affairs

PROJECT CHIEF: Dennis Risser

PERIOD OF PROJECT: October 1977 to September 1980

Problem: Laguna Pueblo needs additional supplies of good-quality water for irrigation and public supply.

Objectives: Determine the quantity and quality of water available and predict the possible effects of present and future water-resources development on the hydrologic system.

PROJECT TITLE: Digital model study of the Mimbres Basin, New Mexico

COOPERATING AGENCY: New Mexico State Engineer office

PROJECT CHIEF : Randal1 T. Hanson

PERIOD OF PROJECT: February 1980 to September 1981

Problem: Additional data and a conceptual/numerical model framework for the water resources of the Mimbres Basin are needed for administration of available water. Water levels are declining; a projected increase in development has resulted in a need to quantify the distribution and movement of the water resources.

Objectives: Compile quantitative data necessary to construct a geohydrologic framework of the water resources and construct a calibrated, steady-state, distributed-parameter, numerical model that simulates ground-water flow in this closed alluvial basin. 
PROJECT TITLE:

COOPERATING AGENCY:

PROJECT CHIEF:

PERIOD OF PROJECT:
Miscellaneous activities under the State Engineer program

New Mexico State Engineer Office

Douglas P. McAda

Continous since January 1960

Problem: The Geological Survey receives many requests from the public for information about the water resources and geology of the State. Occasionally requests are received from the State Engineer office for the compilation of specific data for which no project exists.

Objectives: Conduct spot reconnaissance studies, answer letter and telephone Inquiries, and compile specific data.

PROJECT TITLE: New Mexico District data bank

COOPERATING AGENCY: New Mexico State Engineer Office

PROJECT CHIEF: $\quad$ Ed Thomas

PERIOD OF PROJECT: Continuous since November 1970

Problem: The New Mexico District has recently acquired a minicomputer system. Proper utilization of the increased potential provided by the minicomputer is necessary.

Objectives: Provide new computer applications for better utilization of District and State resources through project support specific to New Mexico's data program needs. 
PROJECT TITLE:

LOCATION :

COOPERATING AGENCY:

PROJECT CHIEFS :

PERIOD OF PROJECT:
Water use - New Mexico

Statewide

New Mexico State Engineer office

William K. Dein, U.S. Geological Survey

Earl F. Sorensen, New Mexico State Engineer office

Continuous since May 1978

Problem: A national program has been developed using a uniform system to collect, store, and retrieve reliable water-use data that will be available for planning, operation, and management purposes. New Mexico presently has a water-use data-collection program that will be modified and expanded to conform to the national program. In addition, there is a need for management of water-use data that will be collected in support of regional aquifer studies in New Mexico.

Objectives: Implement a program in cooperation with the State Engineer office for the collection and computer storage of all water-use data in the State of New Mexico. Develop standard methods for collection, storage, and retrieval at the State level that will conform to those established for the national system. 
PROJECT TITLE:

Quality-of-water montoring in the Chaco River

Basin in northwestern New Mexico's energy

development area

COOPERATING AGENCY: U.S. Environmental Protection Agency

PROJECT CHIEF: Kim Ong

PERIOD OF PROJECT: April 1976 to April 1980

Problem: The demand to develop energy mineral resources in the Chaco River Basin and the concern to protect the environment surrounding these resources have created the need to study the associated hydrologic system. The flow in the Chaco River and the ground water in the channel alluvium will be impacted by these developments. There is concern that adverse impacts may move downstream into the San Juan River and ultimately into the Colorado River. In the past, the water resources of the Chaco River Basin were not studied because the basin is sparsely populated, the natural flow in the Chaco River is ephemeral and unpredictable, the Chaco River's contribution to the total flow in the San Juan River is thought to be small, and the quality of the water resources in the basin is considered to be poor.

Consequently, insufficient water-resource data exist to define adequately the natural conditions and to assess effects of energy developments.

Objective: Collect water-resources data from selected sites along the Chaco River system that may be impacted by energy developments, particularly uranium mining and coal mining. Emphasis is being placed on collecting quality-of-water data, but streamflow data are also being collected. other hydrologic studies have recently been initiated in the Chaco River Basin with their focus on surface coal mining. The data collected under this project combined with the data collected from the other studies will be used to define natural or present water-resources conditions and to assist in resolving water-supply concerns of energy developments. 
PROJECT TITLE:

COOPERATING AGENCY:

PROJECT CHIEF:

PERIOD OF PROJECT:
Hydrologic surveillance of coal-lease areas in northwestern New Mexico

Bureau of Land Management, Federal Coal Management Program (formerly EMRIA-Energy Mineral Rehabilitation Inventory and Analysis)

Henry R. Hejl, Jr.

August 1974 to September 1981

Problem: Certain areas of the San Juan Basin in northwestern New Mexico are undergoing changes mostly related to energy development. Among the developments are strip mining of coal, oil and gas exploration, electric power generation, coal gasification, and agriculture. These developments may affect the condition of the water resources by changing drainage patterns, increasing sediment yield, and altering the chemical quality of water.

Objectives: Document hydrologic characteristics of streamflow and ground water associated with the coal seams and their variabilities in quantity and quality, obtain a knowledge of the flow systems and the principles and processes in effect, and determine the effects of coal extraction and associated development on the quantity and quality of water resources in the coal-lease areas of northwestern New Mexico.

PROJECT TITLE:

PROJECT CHIEF:

PERIOD OF PROJECT:
Water-resources monitoring of coal development In the San Juan Basin, New Mexico

Henry R. Hej1, Jr.

Continuous since January 1977

Problem: Coal mining and associated activities in the San Juan Basin may have an adverse effect on the water resources of the area. Mine dewatering, changes in land use, waste disposal, stream-channel realignment, and water withdrawa1s for industries and municipalities may alter streamflow and ground-water systems, interfere with traditional water uses, or cause deterioration of remaining water resources.

Objectives: Monitor surface and ground water in the coal areas to detect and document changes in water quantity and quality that may result from coal mining and associated activities, and obtain knowledge of the regional flow system and the principles and processes in effect. 
PROJECT TITLE:

Effects of energy-resources development on the hydrogeologic environment of northwestern New Mexico

COOPERATING AGENCIES: New Mexico State Engineer office and New Mexico Bureau of Mines and Mineral Resources

PROJECT CHIEFS :

Peter F. Frenzel, U.S. Geological Survey

William J. Stone, New Mexico Bureau of Mines and Mineral Resources

PERIOD OF PROJECT: August 1974 to September 1980

Problem: Large reserves of minerals are currently being developed in the San Juan Basin of New Mexico. Expanded exploration and production of these minerals will be accompanied by an increasing need for large supplies of water. Production and disposal of waste water in a rather fragile environment is also anticipated. The Bureau of Indian Affairs and numerous communities are concerned with the effects of development of large supplies of ground water in the area. The few available well records in the area indicate that usable ground-water supplies are available locally; however, these probably are somewhat limited.

Objectives: Evaluate the aquifers within the project area. Determine ground-water levels for the various aquifers and the effects of various withdrawal plans on water levels. Determine the chemical and radiochemical quality of the ground water. 
PROJECT TITLE:

COOPERATING AGENCY: Bureau of Land Management, Federal Coal Management Program (formerly EMRIA-Energy Mineral Rehabilitation Inventory and Analysis)

PROJECT CHIEF :

PERIOD OF PROJECT: October 1977 to September 1981

Problem: The effects of surface mining for coal on the quantity and quality of surface flow in the strippable coal-lease area in the San Juan Basin are unknown. The Bureau of Land Management needs to predict the effects of surface mining on the water resources in the coal-lease areas in order to manage the coal-bearing areas of the public domain.

Objectives: Develop, test, and verify precipitation-runoff models for predicting surface-runoff characteristics and sediment yield under various land-use conditions in the coal-lease areas in northwestern New Mexico. Relate parameters used by the model to measurable physical features of a selected basin to facilitate transferability of the model from an instrumented basin to uninstrumented basins.

PROJECT TITLE: Miscellaneous reach studies, Pecos River

COOPERATING AGENCY: Pecos River Commission

PROJECT CHIEF: George E. Welder

PERIOD OF PROJECT: Continuous since July 1969

Problem: The Pecos River Commission, which administers the waters of the Pecos River in New Mexico and Texas, often has need for special studies of the relationship of surface and ground water in specific reaches of the river.

Objectives: Relate gains or losses in streamflow to ground-water flow conditions, transpiration, evaporation, or other flow diversions. 
PROJECT TITLE:

COOPERATING AGENCY:

PROJECT CHIEF :

PERIOD OF PROJECT:
Duties for the Rio Grande Compact Commission

Rio Grande Compact Commission

Pat L. Soule

Continuous since February 1948

Problem: The Rio Grande Compact Commission is composed of representatives of the States of Colorado, New Mexico, and Texas. The administration of the Compact requires that streamflow and water-storage data for that area of the Rio Grande Basin upstream from Fort Quitman, Texas, be collected, compiled, correlated, and presented to the Commission.

Objectives: Perform duties of secretary as outlined in the rules and regulations of the Rio Grande Compact Commission. Principal duty is compilation of streamflow and storage data on a monthly basis; these data are later assembled for publication in the annual report of the Commission.

Reports published or released during fiscal year 1980:

Rio Grande Compact Commission, 1980, Report of the Rio Grande Compact Commission, 1979: 55 p.

PROJECT TITLE: A quantitative analysis of the ground-water system in the Roswell basin, Chaves and Eddy Counties, New Mexico

COOPERATING AGENCY: New Mexico State Engineer Office

PROJECT CHIEF: George E. Welder

PERIOD OF PROJECT: July 1963 to September 1980

Problem: In parts of the Roswell basin, development of ground water for agricultural, municipal, and industrial use has caused large artesian head losses. The drop in hydraulic head is causing movement of saline water into freshwater aquifers and a reduction in quantity and quality of low flow in the Pecos River, an interstate stream. The ground-water supplies in the basin need to be defined.

Objectives: Define the geohydrologic framework of the basin and the longterm hydraulic-head changes in the aquifers. This information will be used in a model analysis of the basin. 
PROJECT TITLE:

COOPERATING AGENCY:

PROJECT CHIEFS :
Ground-water resources of the San Agustin

Plains and adjacent areas, Catron and

Socorro Counties, New Mexico

PERIOD OF PROJECT: October 1978 to September 1981

Problem: The Plains of San Agustin is a basin with interior surface-water drainage. It has been declared by the New Mexico State Engineer as part of the Rio Grande "underground-water basin". Complete information is needed on the quantity, quality, and availability of ground water in the Plains and adjacent areas for the proper management of ground-water resources. Previous to this study, very little information on the ground-water resources had been collected.

Objectives: (1) Collect basic information about wells, springs, geology of aquifers, water use, water chemistry, and aquifer hydraulic coefficients within the study area; (2) analyze the collected data in order to define the availability, quality, and quantity of ground water; and (3) determine the flow systems and relationships of aquifers within the Plains of San Agustin Basin and adjoining basins.

PROJECT TITLE:

Water resources of Santa Fe County, New Mexico

COOPERATING AGENCY: New Mexico State Engineer office

PROJECT CHIEF: $\quad$ Robert R. White

PERIOD OF PROJECT: November 1971 to January 1981

Problem: Several land-development companies have purchased large tracts of land in Santa $\mathrm{Fe}$ County and have made plans for community developments. Water supply may be a problem in the development of these communities. A study of the quantity and chemical quality of the water resources of the county is needed for the use of those concerned with water supply, whether for household, community, stock, irrigation, or industrial use.

Objectives: Obtain geohydrologic data and evaluate aquifer yields, chemical quality of water, relationships between surface and ground water, and the effects of water-use developments in Santa Fe County. 
PROJECT TITLE:

PROJECT CHIEF:
Southwest alluvial basin (east), regional aquifer systems analysis

David W. Wilkins

PERIOD OF PROJECT: September 1979 to September 1982

Problem: The Rio Grande drainage basin from north of Alamosa, Colorado, to Presidio, Texas, is experiencing rapid population growth, which has caused increased pumping from basin aquifers and a search for new sources of fresh ground water. The result is increased stress on the limited water resources of the area. Where surface-water supplies are available, the difference between available surface supplies and consumptive use has been made up by developing ground-water supplies from alluvial fill adjacent to the streams. Where surface supplies are not available, water supplies have been augmented by withdrawing more ground water from alluvial desert basins. Increasing use of ground water has produced declines in ground-water levels, affected through-flowing streams, and initiated water-quality changes. The magnitude of these effects are undefined for the regional aquifer system. In some ground-water basins within the regional aquifer system, these effects are being studied, but the cause-and-effect relationships between basins are largely undefined.

Objectives: The overall objective is to define the hydrology of the regional aquifer system. Specific objectives for the study of ground-water basins in the system are to define: (1) The extent of the aquifers, their hydraulic properties, water quality; (2) the relationship between surface and ground water; (3) the hydraulic connection between basins; and (4) past, present, and probable future stresses. When these basin objectives are met, specific objectives for the study of the regional aquifer system are to describe water-level changes, effects on streamflow, and water-quality changes as a result of past, present, and proposed development.

The study will bring together data collected from many past and present studies and data collected for this study. Digital models of the basin aquifers and regional system will be developed and made available for future use. 
PROJECT TITLE:

COOPERATING AGENCY:

PROJECT CHIEF:

PERIOD OF PROJECT:
Reconnaissance of water resources available to urban areas, New Mexico

New Mexico State Engineer Office

John S. McLean

September 1972 to June 1980

Problem: Only a few urban areas in New Mexico have been evaluated as to the quantity and quality of ground and surface water available for their use. It is known that in certain areas environmental influences have caused deterioration of the chemical quality of water supplies. In some areas better quality water or larger volumes of water may be available from alternate sources.

Objectives: Evaluate certain urban areas and determine if a suitable supply of water for domestic and industrial uses, projected against anticipated future population growth, will be available when needed. Attempt to define influences that may affect the future quality and quantity of the available water.

PROJECT TITLE:

Continuing reconnaissance and evaluation of water resources on the White Sands Missile Range

COOPERATING AGENCY: White Sands Missile Range

PROJECT CHIEF: Jim D. Hudson

PERIOD OF PROJECT: Continuous since July 1960

Problem: The population of the missile range is increasing, as is the use of ground water. Because the volume of fresh ground water is limited, the effects of increasing draft on the reservoir must be known with reference to depletion and to possible saline-water encroachment. Several wells on the missile range supply water to camp areas; continued operation of these wells is vital to the range.

Objectives: Obtain water-level and pumpage data so periodic evaluation of reservoir depletion in the post headquarters area can be made. Monitor test wells for changes in chemical quality of the water. Observe water levels and chemical quality of water from wells in camp areas. Do short-term site studies where additional water supplies are needed. Evaluate approaches for economical recovery of the maximum available freshwater.

Reports published or released during fiscal year 1980:

Cruz, R. R., 1980, Annual water-resources review, White Sands Missile Range, 1979: U.S. Geological Survey Open-File Report 80-753, 25 p. 
PROJECT TITLE:

COOPERATING AGENCY:

PROJECT CHIEF :

PERIOD OF PROJECT:
Hydrologic investigation related to a radioactive-waste repository in salt, southeastern New Mexico

Department of Energy

Jerry W. Mercer

May 1975 to September 1981

Problem: The Department of Energy is evaluating salt beds in southeastern New Mexico for use as a potential repository for medium- to high-level radioactive wastes. Information is needed on the occurrence and movement of water in the various water-bearing beds above and below the salt to assist in evaluation of the long-term hydrologic integrity of the site as well as to assess the environmental impact of the proposed project.

Objectives: Define the general occurrence of ground water in the area from near Roswell southeastward to the State line. Define in detail the direction and rate of movement of ground water in the Rustler Formation in the vicinity of the site, with less detailed definition down-gradient to about 30 miles from the site.

PROJECT TITLE: Water resources of the Zuni Reservation

COOPERATING AGENCY: Pueblo of Zuni

PROJECT CHIEF: $\quad$ Brennon R. Orr

PERIOD OF PROJECT: January 1978 to September 1981

Problem: The Pueblo of Zuni requires information on the yield, variability, and quality of existing water supplies, as well as the potential for developing new supplies. There is potential for industrial development and expansion of the existing communities on the reservation.

Objectives: Provide a comprehensive analysis of the source, supply, chemical quality, and availability of water from streamflow, springs, and wells on the reservation. 
PROJECT TITLE:

COOPERATING AGENCIES:

PROJECT CHIEF :

PERIOD OF PROJECT:
Ground-water resources of central and western Valencia County, New Mexico

New Mexico State Engineer office

New Mexico Bureau of Mines and Mineral Resources

Joe A. Baldwin

April 1980 to June 1982

Problem: Ground-water information is almost totally absent for much of western and central Valencia County. Extensive aquifers such as the basalt flows (malpais) and underlying alluvium of the North Plains, the limestone aquifers south and west of the Zuni Mountains, and extensive sandstone aquifers of Triassic through Tertiary age have not been assessed. Less developed areas of the county are being considered for possible development because of their proximity to major energy-producing areas.

Objectives: Define the ground-water resources of central and western Valencia County by conducting a well and spring inventory throughout the study area. Conduct aquifer tests and water-quality analyses where possible. Compile a geologic map of the study area.

PROJECT TITLE:

COOPERATING AGENCY:

PROJECT CHIEF :

PERIOD OF PROJECT:
Digital-model study of the Roswell basin, New Mexico

New Mexico State Engineer office

Paul A. Davis

October 1979 to September 1982

Problem: The Roswell ground-water basin is the major source of water for irrigation in Chaves and Eddy Counties. An understanding of the interaction between the components of the ground-water system is essential in all aspects of ground-water development.

Objectives: Produce a digital model that simulates the major components of the ground-water basin and their interaction. 
PROJECT TITLE:

COOPERATING AGENGY:

PROJECT CHIEF :

PERIOD OF PROJECT:
Model of the Ogallala aquifer system, Lea County, New Mexico

New Mexico State Engineer office

Douglas P. McAda

March 1980 to September 1982

Problem: Increased demand for water in the High Plains region of Lea County, New Mexico, is causing water-level declines in the Ogallala aquifer. The quantity of water in storage is not accurately known, nor has the quantity of water being pumped been determined. This area will be adversely affected by partial depletion of the aquifer.

Objectives: Estimate the present quantity of water in the Ogallala aquifer and predict future water-level declines based on anticipated water use in the county. The results of the study will benefit municipal planners and industrial water users in estimating the quantities of water available for their use in the future.

PROJECT TITLE: $\quad$ Exploration of techniques for separation and quantification of individual coal-mine effects from cumulative effect data

PROJECT CHIEF: Carole L. Goet $z$

PERIOD OF PROJECT: April 1980 to October 1982

Problem: Legal requirements of regulatory agencies have created a need to evaluate the hydrologic effects of proposed and actual coal mining activities. The situation on the San Juan River in northwestern New Mexico offers a promising set of circumstances to determine whether the effects of a single coal mine are large enough to be measured and separated from other natural and cultural effects using the cumulative hydrologic data collected at stream sites by the U.S. Geological Survey.

Objectives: Investigate various data-analysis techniques that can be used to quantify and separate individual coal-mine effects on streamflow, water quality, and sedimentation from cumulative natural and cultural effects. 


\section{PUBLICATIONS OF THE U.S. GEOLOGICAL SURVEY AND REFERENCE SOURCES ON THE HYDROLOGY AND GEOLOGY OF NEW MEXICO}

Professional Papers, Water-Supply Papers, Bulletins, Circulars, and the Yearbook of the Geological Survey are available from the U.S. Geological Survey, Branch of Distribution, 1200 South Eads Street, Arlington, Virginia 22202 (authorized agent of the Superintendent of Documents, Government Printing office). Hydrologic Investigations Atlases, Hydrologic Unit Maps, topographic maps, and other maps pertaining to New Mexico are sold by the U.S. Geological Survey, Branch of Distribution, P.0. Box 25286, Federal Center, Denver, Colorado 80225. Microfiche and black and white paper copies of open-file reports may be obtained from the Open-File Services Section, Branch of Distribution, U.S. Geological Survey, P.0. Box 25425, Federal Center, Denver, Colorado 80225. The Water-Resources Investigations series is available from the National Technical Information Service, U.S. Department of Commerce, 5285 Port Royal Road, Springfield, Virginia 22151 .

Records of streamflow, ground-water levels, and quality-of-water data were published for many years as Geological Survey Water-Supply Papers (WSP) in the series explained below. Beginning with the 1975 water year, these series have been replaced by a new publication series, "U.S. Geological Survey Water-Data Reports." This new series combines streamflow data, water-quality data for surface and ground water, and ground-water-level data from the basic network of observation wells. For New Mexico, the first report of this series was entitled "Water Resources Data for New Mexico Water Year 1975: U.S. Geological Survey Water-Data Report NM-75-1." Other publication series of general interest are explained below. Further information on these publications can be obtained from the District Chief, U.S. Geological Survey, Water Resources Division, P.0. Box 26659, Albuquerque, New Mexico 87125.

Streamflow records.--Records of daily flows of streams prior to 1971 were published in the Water-Supply Paper series "Surface-Water Supply of the United States" which was released in numbered parts as determined by natural drainage basins. Until 1961 this was an annual series; monthly and yearly summaries of these data were compiled in two reports: "Compilation of Records of Surface Waters of the United States through September 1950" and "Compilation of Records of Surface Waters of the United States, October 1950 to September 1960." For the period 1960-70, two 5-year compilations were published. Data for New Mexico are published in part 7 , volume 2 ; part 8 , volumes 1 and 2 ; and part 9 , volumes 2 and 3 . For the years 1961-74, these data also were released annually on a state-boundary basis. 
Ground-water records.--Prior to 1975 ground-water levels and artesian pressures in observation wells were reported by geographic areas in a Water-Supply Paper series published at 5-year intervals. Data for New Mexico are found in "Ground-Water Levels in the United States, Southern States." The New Mexico State Engineer office also publishes ground-water data in a hydrologic-data series entitled, "Ground-Water Levels in New Mexico."

Quality-of-water records.--Data for quality of surface water prior to 1971 were published annually in the Water-Supply Paper series "Quality of Surface Waters of the United States," which also was released in numbered parts as determined by natural drainage basins. Data for New Mexico are in parts 7, 8, and 9. For the years 1964-74, these data also were released annually on a state-boundary basis.

Methods of estimating the frequency and magnitude of floods for selected streams are given in the Water-Supply Paper series "Magnitude and Frequency of Floods in the United States," which is composed of reports released in parts by drainage basins; data for New Mexico are in parts 7, 8, and 9. The Geological Survey also has outlined flood-prone areas on topographic maps as part of a nationwide Federal program for managing flood losses. In New Mexico, 67 topographic maps have been completed. Flood-prone area maps of New Mexico are listed in "Index of flood maps prepared by the U.S. Geological Survey through 1973," Water Resources-Investigations 57-73. Information on these maps is available from the District Chief, Water Resources Division, Albuquerque.

Summaries of research in progress and results of completed investigations are published each fiscal year in the Professional Papers "Geological Survey Research." Recent editions are: fiscal year 1974, PP 900; 1975, PP 975, PP 1000; 1977, PP 1050; 1978, PP 1100.

Summary statements about the immediate national water situation are presented in the Water Resources Review, which is issued monthly. The Review may be obtained free on application to the U.S. Geological Survey, 420 National Center, Reston, Virginia 22092.

Indexes to the "Catalog of Information on Water Data" are available free from the District Chief in Albuquerque or the Office of Water Data Coordination, U.S. Geological Survey, 417 National Center, Reston, Virginia 22092. Current editions are as follows: (1) station listings for streamflow and stage, quality of surface water, and quality of ground water, 1974 [21 volumes by water-resources regions--stations in New Mexico are listed in volumes 11 (Arkansas-White-Red Region), 12 (Texas-Gulf Region), 13 (Rio Grande Region), 14 (Upper Colorado Region), and 15 (Lower Colorado Region)]; (2) index to areal investigations and miscellaneous water-data activities, 1970 (one volume); and (3) index to ground-water stations, 1968 (one volume). 
The "U.S. Geological Survey Annual Report" (known as the "Yearbook" since 1977) provides a comprehensive description of the Federal Government's largest earth-science agency.

Topographic maps for New Mexico may be purchased from the Branch of Distribution, U.S. Geological Survey, Box 25286, Federal Center, Denver, Colorado 80225. Available free from the same address is an "Index to Topographic Maps of New Mexico" which is updated periodically to show current availability. A quarterly edition of "Advance Material Available," which details the status of current mapping programs, is issued by the U.S. Geological Survey, Rocky Mountain Mapping Center, Federal Center, Box 25046, MS 504, Denver, Colorado 80225. Unedited advance prints are often available more than a year before maps are published in final form.

U.S. Geological Survey topographic maps may be purchased from private dealers in every major city in the State. Dealer prices may be slightly higher than Survey prices.

Many libraries maintain reference files of the published maps of the Geological Survey. In New Mexico, maps are deposited in the libraries listed below:

Albuquerque: Library, University of New Mexico

Las Cruces: Documents Division, New Mexico State University

Las Vegas: Donnelly Library, New Mexico Highlands University

Santa Fe: New Mexico State Library, Museum of New Mexico

Socorro: New Mexico Bureau of Mines and Mineral Resources

A book entitled "Publications of the Geological Survey, 1879-1961" 1ists a11 books published by the Survey through 1961. A supplement 1ists publications issued between 1962 and 1970, and annual supplements have appeared since that time. A monthly series, "New Publications of the Geological Survey," lists the most recent books and maps published by the Survey.

A complete compilation of reports is given in "List of Geological Survey Geologic and Water-Supply Reports and Maps for New Mexico." This list is available free from the Branch of Distribution, U.S. Geological Survey, 1200 S. Eads Street, Arlington, Virginia 22202.

The Survey has published four bibliographies for parts of New Mexico, listing publications from all sources. The first of these, printed in 1978, is USGS Bulletin 1458, entitled "Bibliography of the Geology and Hydrology of the Albuquerque Greater Urban Area, Bernalillo and Parts of Sandoval, Santa Fe, Socorro, Torrance, and Valencia Counties, New Mexico." Another list was published in 1979 as Water-Resources Investigations 79-76, entitled "Bibliography of Geology and Hydrology, Eastern New Mexico." "Bibliography of Geology and Hydrology, San Juan Basin, New Mexico, Colorado, Arizona, and Utah" was published in 1979 as Bulletin 1481. A bibliography on southwestern New Mexico was published as Water-Resources Investigations 80-20. These four publications are for sale from the Branch of Distribution in Arlington. 
The New Mexico State Engineer office in 1978 published a "Bibliography of Ground-Water Studies in New Mexico, 1873-1977" (compiled by Robert L. Borton). An update of this has also been published. This is the most complete bibliography available on a statewide basis. It is available without cost from the New Mexico State Engineer office, Bataan Memorial Building, Santa Fe, New Mexico 87503. A list of publications by the State Engineer office may be obtained from the same address.

The New Mexico Water Resources Research Institute, located at New Mexico State University, coordinates a wide variety of water studies. A free list of publications may be obtained by writing the Institute at P.0. Box 3167 , Las Cruces, New Mexico 88003.

A free list of the publications of the New Mexico Bureau of Mines and Mineral Resources may be obtained from the Bureau at Socorro, New Mexico 87801. Bureau publications include mining, geology, hydrology, and energy resources statewide. The Bureau offers for sale a "Bibliography of New Mexico Geology and Mineral Technology" in their Bulletin series. Publications of the New Mexico Geological Society may also be purchased from the Bureau of Mines and Mineral Resources.

A list of theses and dissertations by geology students at the University of New Mexico may be obtained from the Department of Geology, University of New Mexico, Albuquerque, New Mexico 87131. A "Bibliography of Dissertations and Theses on Water and Water Related Topics from New Mexico State University through December 1980" by Robert G. Myers and Karen M. Pinckley may be obtained from the New Mexico Water Resources Research Institute in Las Cruces.

A general historical and cultural bibliography of New Mexico is "20,000 Years of History--A New Mexico Bibliography", by Frances Leon Swadesh. There are some geologic and irrigation references. Other historical references to irrigation and water-right conflicts can be found in the indexes to the "New Mexico Historical Review" and "El Palacio" (Bulletin of the Museum of New Mexico). The "New Mexico Historical Review" index should be available for use at all major libraries in the state, and the "E1 Palacio" index is available at the Zimmerman Library at the University of New Mexico. 
Cruz, R. R., 1980, Annual water-resources review, White Sands Missile Range, New Mexico, 1979: U.S. Geological Survey Open-File Report 80-753, 25 p., 11 figs.

Havens, J. S., and Wilkins, D. W., 1979, Experimental salinity alleviation at Malaga Bend, Eddy County, New Mexico: U.S. Geological Survey Water-Resources Investigations $80-4,65$ p., $23 \mathrm{figs}$.

Hearne, G. A., 1980, Simulation of an aquifer test near Tesuque Pueblo, New Mexico: U.S. Geological Survey Open-File Report 80-1022, 41 p., 17 figs.

1980, A mathematical model of the Tesuque aquifer system underlying Pojoaque River Basin and vicinity, New Mexico: U.S. Geological Survey Open-File Report 80-1023, 181 p., 81 figs.

Hej1, H. R., Jr., 1980, Preliminary appraisal of ephemeral-streamflow characteristics as related to drainage area, active-channel width, and soils in northwestern New Mexico: U.S. Geological Survey Open-File Report 81-64, 29 p., 1 fig.

Hudson, J. D., 1980, A compilation of hydrologic data before and during highway construction in parts of Tijeras Canyon, New Mexico, 1972-1978: U.S. Geological Survey Open-File Report 80-332, 80 p., 5 figs.

1980, Ground-water depletion, in feet, allowed in a part of Curry County, New Mexico, by U.S. Internal Revenue Service for calendar year 1979: New Mexico State Engineer Map CU-20, 1 sheet.

1980, Ground-water depletion, in feet, allowed in the central part of Lea County, New Mexico, by U.S. Internal Revenue Service for calendar year 1979: New Mexico State Engineer Map LC-22, 1 sheet.

1980, Ground-water depletion, in feet, allowed in the northern part of Lea County, New Mexico, by U.S. Internal Revenue Service for calendar year 1979: New Mexico State Engineer Map LN-22, 1 sheet.

1980, Ground-water depletion, in feet, allowed in Portales Valley, Roosevelt County, New Mexico, by U.S. Internal Revenue Service for calendar year 1979: New Mexico State Engineer Map R0-23, 1 sheet.

Kunkler, J. L., 1980, Evaluation of the Malaga Bend salinity alleviation project, Eddy County, New Mexico: U.S. Geological Survey Open-File Report 80-1111, 33 p., 5 figs. 
Lyford, F. P., and Frenzel, P. F., 1980, Modeled effects of uranium development on ground-water and surface-water resources in northwestern New Mexico, published in the proceedings of the Grants Uranium Symposium.

McLean, J. S., 1980, Aquifer tests in the Gallup Sandstone near Yah-ta-hey, New Mexico: U.S. Geological Survey Water-Resources Investigations 80-25, 25 p., 14 figs.

Mourant, W. A., 1980, Hydrologic maps and data for Santa Fe County, New Mexico: New Mexico State Engineer Basic Data Report, 180 p., 4 figs.

Posson, D. R., 1980, Prototype minicomputer specification design, procurement, and installation in WRD District and research offices: U.S. Geological Survey Open-File Report 80-326.

Posson, D. R., Hearne, G. A., Tracy, J. V., and Frenze1, P. F., 1980, A computer program for simulating geohydrologic systems in three dimensions: U.S. Geological Survey Open-File Report 80-421, 795 p., 19 figs.

Reiland, Louis J., 1980, Flow characteristics of New Mexico streams: New Mexico State Engineer Special Report, 115 p., 9 figs.

Rio Grande Compact Commission, 1980, Report of the Rio Grande Compact Commission, 1979: 55 p.

Titus, Frank B., 1980, Ground water in the Sandia and northern Manzano Mountains, New Mexico: New Mexico Bureau of Mines and Mineral Resources Hydrologic Report 5, 66 p., 22 figs.

U.S. Geological Survey, 1980, Water Resources Data for New Mexico, Water Year 1979: U.S. Geological Survey Water-Data Report NM-79-1, 747 p.

1980, Annual Report to the Pecos River Commission: $21 \mathrm{p}$.

White, R. R., and Dein, W. K., 1980, Water-resources investigations of the U.S. Geological Survey in New Mexico, fiscal year 1979: U.S. Geological Survey Open-File Report 80-408, 77 p., 28 figs.

Wilkins, D. W., Scott, W. B., and Kaehler, C. A., 1980, Planning report for the southwest alluvial basins (east) regional aquifer-system analysis, parts of Colorado, New Mexico, and Texas: U.S. Geological Survey Open-File Report 80-564, 39 p., 6 figs.

Wright, Ann F., 1980, Bibliography of geology and hydrology, southwestern New Mexico: U.S. Geological Survey Water-Resources Investigations 80-20, 255 p., 1 fig. 